\title{
A New Bianthron Glycoside as Inhibitor of Trypanosoma cruzi Glyceraldehyde 3-Phosphate Dehydrogenase Activity
}

\author{
Edângelo M. S. de Macedo, ${ }^{a}$ Helton J. Wiggers, ${ }^{b}$ Maria G. V. Silva, ${ }^{*, a, b}$ Raimundo Braz-Filho, ${ }^{c}$ \\ Adriano D. Andricopulo ${ }^{d}$ and Carlos A. Montanari ${ }^{b}$
}

\author{
a'Departamento de Química Analítica e Físico-Química, Departamento de Química Orgânica e Inorgânica, \\ Universidade Federal do Ceará, 60455-970 Fortaleza-CE, Brazil \\ ${ }^{b}$ Instituto de Química de São Carlos and IInstituto de Física de São Carlos, Universidade de São Paulo, \\ 13560-970 São Carlos-SP, Brazil
}

\author{
'Setor de Química de Produtos Naturais, CCT, Universidade Estadual do Norte Fluminense, \\ 28013-602 Campos dos Goytacazes-RJ, Brazil
}

\begin{abstract}
A investigação fitoquímica do extrato etanólico do caule de Senna martiana Benth. (Leguminoseae), espécie nativa do nordeste do Brasil, permitiu o isolamento e caracterização espectroscópica de uma biantrona inédita denominada martianina (1), 10,10'-H-bicrisofanol10-ox-10,10'-biglucosil. Sua identificação estrutural inequívoca foi estabelecida por HRMS, IV e RMN de ${ }^{1} \mathrm{H}$ e ${ }^{13} \mathrm{C}$ uni e bi-dimensional. A atividade tripanocida de martianina foi avaliada por seu comportamento frente à enzima $\mathrm{GAPDH}_{\mathrm{Tc}}$ através da obtenção de sua constante de inibição

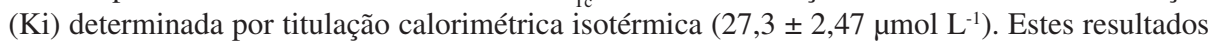
sugerem que esta classe de molécula tem potencial no desenvolvimento de novos fármacos a serem utilizados contra a doença de Chagas.
\end{abstract}

A phytochemical investigation of the ethanolic extract of stalks of Senna martiana Benth. (Leguminoseae), native specie of northeast Brazil, resulted in the isolation and spectroscopic characterization of a new bianthrone glycoside, martianine $\mathbf{1}(10,10$ '-il-chrysophanol-10-oxi10,10'-bi-glucosyl). Its identification was established by HRMS, IR and 2D NMR experiments. The evaluation of martianine trypanocidal activity was carried out against gliceraldehyde 3-phosphate dehydrogenase enzyme from Trypanosoma cruzi. Its inhibitory constant $\left(\mathrm{K}_{\mathrm{i}}\right)$ is in the low micromolar concentration and it was determined by isothermal titration calorimetry to be $27.3 \pm 2.47 \mu \mathrm{mol} \mathrm{L}{ }^{-1}$. The non-competitive mechanism is asserted to be putative of the mode of action martianine displays against T. cruzi GAPDH. Results show that martianine has a great potential to become new lead molecule by inhibiting this key enzyme and for the development of new drugs against Chagas disease.

Keywords: Senna martiana, Leguminoseae, bianthrone, anthraquinone, Trypanosoma cruzi, isothermal titration calorimetry

\section{Introduction}

Senna martiana (Benth) I\&B (Leguminoseae), is a native specie of northeast Brazil and it is a shrub presenting abundant foliages and exuberant yellow flowers. This plant is locally known as "canafístula brava" and "caixão de canafístula". ${ }^{1}$ Previous chemical studies do not exist about $S$. martiana but others species of the genus Senna, have shown to be in great occurrence of anthraquinone

*e-mail: mgvsilva@ufc.br compounds, isolated from several parts of the plant with less incidence in the leaves. ${ }^{2,3}$ The anthraquinone compounds are distributed widely in the nature, mainly as being responsible for the pigmentation and are found in fungi, superior plants and lichens. ${ }^{4}$ There are reports of several biological activities attributed to the presence of anthraquinones such as antioxidant, laxative, antiviral, antimicrobial and trypanocidal. ${ }^{5-9}$

Chagas disease (also called American Trypanosomiasis) is caused by the flagellate protozoa Trypanosoma cruzi. It is estimated that $16-18$ million people are infected in 18 
countries of Latin America and in the US 100,000-675,000 immigrants from Latin America are infected with T. cruzi. It is one of the most neglected diseases in the world and lack of financial support is one of the major characteristic avoiding the fulfillment of proper investigations. At present, the available drugs nifurtimox (Lampit ${ }^{\mathrm{TM}}$, Bayer) and benznidazole (Rochagan ${ }^{\mathrm{TM}}$, Radanil ${ }^{\mathrm{TM}}$, Roche) have strong side effects along with low efficacy in addition of being used only in the acute stage of the disease. ${ }^{10,11}$

New molecules with trypanocidal activity are scarce and most of them have low affinity for their biochemical targets. Among the available targets claimed to be of importance in the search for inhibitors is the gliceraldehyde-3-phosphate dehydrogenase (GAPDH), an enzyme of the T. cruzi glycolytic pathway. Although there is a growing interest in GAPDH as trypanocidal target against $T$. cruzi, a literature survey of known GAPDH inhibitors reveals none identified to date by Aronov et al. ${ }^{12}$ Tomazela et al.,$^{13}$ De Marchi et al. ${ }^{14}$ and Ladame et al. ${ }^{15}$ Thus, the need for discovering inhibitors to act against T. cruzi glicossomal GAPDH of interest in the Chagas disease has stimulated our group to begin a structure-based drug design study using isothermal titration calorimetry (ITC). In doing so, the discovery of new trypanocidal lead compounds can be dealt with. ${ }^{16}$

In the present work, we describe the isolation and structural elucidation of a new bianthron glycoside for us dubbed martianine (1) from stalks of Senna martiana Benth. Its spectroscopic ${ }^{1} \mathrm{H}$ and ${ }^{13} \mathrm{C}$ NMR data with $2 \mathrm{D}$ NMR experiments $\left({ }^{1} \mathrm{H}-{ }^{-1} \mathrm{H}\right.$ COSY, HSQC, and HMBC) confirmed the proposed structure. Its activity against $T$. cruzi was evaluated by isothermal titration calorimetry using the enzyme glyceraldehyde-3-phosphate dehydrogenase (GAPDH) as a potential target.

\section{Experimental}

\section{General}

IR spectra were recorded on Perkin Elmer, model FT-IR Spectrum 1000. NMR spectra were obtained on a Bruker, DPX-500 instrument operating at $500 \mathrm{MHz}$ for ${ }^{1} \mathrm{H}$ and $125 \mathrm{MHz}$ for ${ }^{13} \mathrm{C}$. Chemical shifts $(\delta)$ are reported in ppm using solvent signal as the internal standard. ${ }^{1} \mathrm{H}-$, ${ }^{13} \mathrm{C}-\mathrm{NMR}, \mathrm{DEPT}-135$ (to determine carbon multiplicities) spectra were recorded, as well as two-dimensional NMR spectra: COSY to investigate ${ }^{1} \mathrm{H}-{ }^{1} \mathrm{H}$ correlations, HSQC for one-bond ${ }^{13} \mathrm{C}-{ }^{1} \mathrm{H}$ correlations, and $\mathrm{HMBC}$ for a long-range ${ }^{13} \mathrm{C}-{ }^{1} \mathrm{H}$ correlations. Two-dimensional NMR experiments were carried out using pulsed field gradients.
Mass spectra were recorded on an ultrOTOF ${ }_{Q}$ ESI-TOF Mass Spectrometer, instrument of Bruker Daltonics, Billerica, MA, EUA, under the following conditions: infusion pump, flow $300 \mu \mathrm{L} \mathrm{h}^{-1}$, NA-TFA at $10 \mathrm{mg} \mathrm{mL}^{-1}$ was used for internal calibration and $\mathrm{HCO}_{2} \mathrm{Na} 10 \mathrm{mmol} \mathrm{L}^{-1}$ for external calibration.

\section{Plant material}

The stalks of $S$. martiana was collected at in Apodi plateau, Rio Grande do Norte State, Brazil in May 2003, and identified by Prof. Edson de Paula Nunes of the Biology Department, University Federal of Ceará (UFC). A voucher specimen (32440) has been deposited in the Herbarium of Biology Department-UFC, Fortaleza, CE, Brazil.

\section{Extraction and isolation}

Air-dried powdered stem of S. martiana $(3020 \mathrm{~g})$ was exhaustively extracted with EtOH by maceration. The extract was concentrated under vacuum to afford $70 \mathrm{~g}$ residue and was chromatographed on sand (60 mesh) previously treated. The measurements of the used column were of $8.0 \mathrm{~cm}$ of diameter for $60.0 \mathrm{~cm}$ of height, the amount of used fixed phase was of $500 \mathrm{~g}$. Using $\mathrm{C}_{6} \mathrm{H}_{14}$, $\mathrm{CH}_{2} \mathrm{Cl}_{2}$, EtOAc, $\mathrm{MeOH}$ as movable phase, where was collected 11 fractions of $125 \mathrm{~mL}$ each. The $\mathrm{CH}_{2} \mathrm{Cl}_{2}$ fraction $(10.7 \mathrm{~g})$ was purificated using $130 \mathrm{~g}$ of silica gel (VETEC, $\phi \mathrm{mm}$ 0.063-0.200) in a chromatographic column of $5.0 \mathrm{~cm}$ of diameter for $50 \mathrm{~cm}$ of height and using a gradient of increasing polarity of $\mathrm{C}_{6} \mathrm{H}_{14}, \mathrm{CH}_{2} \mathrm{Cl}_{2}$, EtOAc and $\mathrm{MeOH}$ pure or in binary combinations. The combinations had observed the following ratio: 1:0, 4:1, 1:1, 1:4 and 0:1 and for each mobile phase used, 5 fractions of $50 \mathrm{~mL}$ had been collected. Fractions thus collected were analyzed through CCD on silica gel (Sigma Chemical CO, $\phi \mu \mathrm{m} 2-25$ ). Spots were detected under UV (254 and $356 \mathrm{~nm}$ ), vanillinsulfuric acid was used as a standard spraying reagent and plates were heated in an oven at $110{ }^{\circ} \mathrm{C}$ for 5 minutes. The fractions gotten from the eluents $\mathrm{CH}_{2} \mathrm{Cl}_{2}$ :EtOAc (1:4) and pure EtOAc, had been mixed $(715 \mathrm{mg})$, in accordance with the similarity present for CCD. This material was purified by column chromatography on silica gel (VETEC, $\phi \mathrm{mm}$ 0.063-0.200) using $\mathrm{C}_{6} \mathrm{H}_{12}-\mathrm{CH}_{2} \mathrm{Cl}_{2}$ (100:0, 1:1 and 0:100) and $\mathrm{CH}_{2} \mathrm{Cl}_{2}$-EtOAc (4:1, 1:1, 1:4 and 0:1) in a column of $3.0 \mathrm{~cm}$ of diameter for $40.0 \mathrm{~cm}$ of height, using $50 \mathrm{~g}$ of silica gel. The fractions were collected in a volume of $10 \mathrm{~mL}$ in a total of 65 fractions each. The fractions 28-34, gotten from $\mathrm{CH}_{2} \mathrm{Cl}_{2}$ :EtOAc (1:4 and 0:1), gave $36 \mathrm{mg}$ of compound $\mathbf{1}$ presenting as solid dark orange (bianthron glycoside, martianine). 
10,10'-il-chrysophanol-10-oxi-10,10'-bi-glucosyl (Martianine 1)

$[\alpha]_{\mathrm{D}}^{25}:\left(c 1.0 \mathrm{mg} \mathrm{mL}^{-1}\right.$, acetone $)$; dark orange solid, acetone, 168.2-170.1 ${ }^{\circ} \mathrm{C},{ }^{1} \mathrm{H}-\mathrm{NMR}\left(500 \mathrm{MHz}\right.$, acetone-d6, $\delta$ ), ${ }^{13} \mathrm{C}$ NMR $(125 \mathrm{MHz}$, acetone-d6, $\delta$ ): see Table 1.

\section{Isothermal titration calorimetry and enzyme kinetics}

All titration experiments were carried out using an Isothermal Titration Calorimetry instrument (VPITC, MicroCal, Northampton, USA). ${ }^{17}$ Reaction cells $(1.43 \mathrm{~mL})$ were filled with solutions and equilibrated at $25{ }^{\circ} \mathrm{C}$. After this equilibration, an additional delay period was allowed to generate the baseline used in the subsequent data analyses. All solutions were degassed by use of a vacuum degasser (ThermoVac, MicroCal) for 5 min prior to any experimental run. Stirring speed was maintained at $307 \mathrm{rpm}$ and heat-flow $\left(\mu \mathrm{cal} \mathrm{s} \mathrm{s}^{-1}\right.$ ) was recorded as a function of time.

\section{Enzyme assays}

Expression and purification of the glycossomal Trypanosoma cruzi gliceraldehyde-3-phosphate dehydrogenase GAPDH (EC 1.2.1.12) were carried out as described previously. ${ }^{18}$ The concentration of GAPDH after the dialysis against TEA buffer was determined by Bradford Method, ${ }^{19}$ glycerol $10 \% \mathrm{v} / \mathrm{v}$ was added in the solution at the final concentration of $2 \mu \mathrm{mol} \mathrm{L}^{-1}$ and stocked at $-80{ }^{\circ} \mathrm{C}$. Isothermal titration experiments were carried out with stock solutions of GAPDH in glycerol kept at $-80{ }^{\circ} \mathrm{C}$. The solution was diluted to final enzyme concentration of $5.0 \mathrm{nmol} \mathrm{L}^{-1}$. The concentration of glycerol was negligible after stock solution dilution, since only $5 \mu \mathrm{L}$ of the stock solution was mixed with $2.0 \mathrm{~mL}$ enzyme reaction buffer and no significant change in the instrument thermal power was observed. The D,L-glyceraldehyde3-phosphate (G3P), TEA-HCl, $\beta$-mercaptoethanol, $\mathrm{NaHAsO}_{4} \cdot 7 \mathrm{H}_{2} \mathrm{O}, \mathrm{NAD}^{+}$, DMSO $(99.9 \%)$ and methanol (99.9) were purchased from Sigma (USA). GAPDH normally forms 1,3-diphosphoglycerate when phosphate is present. Arsenate is the substitute for phosphate in this study reaction for minimizing the enzyme product inhibition. The enzyme GAPDH was dialyzed against a solution of TEA-HCl buffer pH $7.50 .1 \mathrm{~mol} \mathrm{~L}^{-1}$, $\beta$-mercaptoethanol $1.0 \mathrm{mmol} \mathrm{L}^{-1}, \mathrm{NaHAsO}_{4} \cdot 7 \mathrm{H}_{2} \mathrm{O}, 30 \mathrm{mmol} \mathrm{L}^{-1}$ and $\mathrm{NAD}^{+}$ $1.5 \mathrm{mmol} \mathrm{L}^{-1}$. Due to stability, activity and reproducibility of the assays not seen in other buffered solutions like Tris- $\mathrm{HCl}$ and phosphate the TEA-HCl was elected to be the choice for all experiments being carried out using this stock solution.
The multiple injection method was chosen due presence of product inhibition..$^{20}$ There are two fundamentally different calorimetric approaches: single injection and multiple injection assay. The advantage of the latter approach is that the amount of product formed is negligible. Hence, it is assured that product inhibition does not significantly influence the measurements (see references 3 and 4 for more details on these methods).

The apparent enthalpy $\left(\Delta \mathrm{H}_{\text {app }}\right)$ of conversion of G3P to 1-arseno-3-phosphoglycerate was determined by filling the sample cell with the D,L-glyceraldehyde-3-phosphate (G3P) $1.0 \mathrm{mmol} \mathrm{L}^{-1}$, TEA-HCl buffer $\mathrm{pH} 7.50 .1 \mathrm{~mol} \mathrm{~L}^{-1}$ $\beta$-mercaptoethanol $1.0 \mathrm{mmol} \mathrm{L}-1, \mathrm{NaHAsO}_{4} \cdot 7 \mathrm{H}_{2} \mathrm{O}$ $30.0 \mathrm{mmol} \mathrm{L}^{-1}$ and $\mathrm{NAD}^{+} 1.4 \mathrm{mmol} \mathrm{L}^{-1}$. The syringe was loaded with the enzyme $1 \mu \mathrm{mol} \mathrm{L}^{-1}$ in the same cell solution and titrated by an injection of $10 \mu \mathrm{L}$; the final enzyme concentration in the cell was $7 \mathrm{nmol} \mathrm{L}{ }^{-1}$. The complete G3P depletion was observed making the reaction come to an end and the instrumental thermal power returned to the initial baseline. The dilution of the enzyme was determined at same experimental conditions, in absence of G3P. The integration of the area under the curve for enzyme assay, after subtracted on the dilution heat, gives the value of $\Delta \mathrm{H}_{\text {app }}$ obtained for all biochemical reactions.

In the kinetic assays the sample cell was loaded with GAPDH $5 \mathrm{nmol} \mathrm{L}^{-1}$, TEA-HCl buffer $\mathrm{pH} 7.50 .1 \mathrm{~mol} \mathrm{~L}^{-1}$, $\beta$-mercaptoethanol $1.0 \mathrm{mmol} \mathrm{L}^{-1}, \mathrm{NaHAsO}_{4} \cdot 7 \mathrm{H}_{2} \mathrm{O}$, $30 \mathrm{mmol} \mathrm{L}^{-1}, \mathrm{NAD}^{+} 1.4 \mathrm{mmol} \mathrm{L}^{-1}$ and DMSO $5.0 \% \mathrm{v} / \mathrm{v}$. The experiments were carried out in absence of martianine and presence of $50 \mu \mathrm{mol} \mathrm{L}^{-1}$ for inhibition enzyme assay. The syringe was loaded with G3P $\left(5 \mathrm{mmol} \mathrm{L}^{-1}\right)$ in the same buffer solution as for the one in the sample cell and titrated by 25 injections of $4 \mu \mathrm{L}$ each. The interval between each injection was $60 \mathrm{~s}$. Under these conditions, it was not observed any significant product inhibition.

\section{Data analysis}

Analyses of the raw data were performed with Origin version 7.0 software. ${ }^{21}$ To carry out the calculations, the data representing the heat effects due to substrate dilution into buffer and mixing were subtracted from the heat-flow raw data. The remaining data represent the reaction progress curve, which were analyzed in Enzyme Assay mode in Origin software. Kinetic parameters $\left(\mathrm{K}_{\mathrm{M}}\right.$ and $\left.\mathrm{k}_{\mathrm{cat}}\right)$ as well as the apparent enthalpy $\left(\Delta \mathrm{H}_{\text {app }}\right)$ for the reaction of G3P conversion to 1-arseno-3-phosphoglycerate were also calculated by use of Origin version 7.0 software. The inhibition constant $\left(\mathrm{K}_{\mathrm{i}}\right)$ was obtained by nonlinear least-squares fit of the experimental data to the non-competitive inhibition Michaelis-Menten equation in SigmaPlot 9.0 software. 


\section{Results and Discussion}

\section{Martianine (1)}

Compound $\mathbf{1}$ was isolated as a dark orange pigment and identified from the ethanolic extract stem $S$. martiana. Its molecular formula $\mathrm{C}_{42} \mathrm{H}_{42} \mathrm{O}_{16}$ was established by HRMS $\left[\mathrm{m} / z 859\left(\mathrm{M}+\mathrm{H}_{2} \mathrm{O}+\mathrm{Na}^{+}\right)\right]$. The IR spectrum showed a broad band at $3401 \mathrm{~cm}^{-1}$ for free $\mathrm{OH}$ groups, aromatic system at 1609,1487 and $1452 \mathrm{~cm}^{-1}$ and a sharp $(\mathrm{C}=\mathrm{O}$ stretch) peak at $1638 \mathrm{~cm}^{-1}$. The structure was deduced from detailed analysis of ${ }^{1} \mathrm{H}$ and ${ }^{13} \mathrm{C}$ NMR data aided by mean of 2D NMR experiments $\left({ }^{1} \mathrm{H}-{ }^{1} \mathrm{H}\right.$ COSY, HSQC, and HMBC) (Table 1). The character dimeric is observed in the spectrum of ${ }^{1} \mathrm{H}$ NMR and ${ }^{13} \mathrm{C}$ NMR, because all the signs appear in a duplicated way. In the NMR ${ }^{1} \mathrm{H}$ spectrum, the signals at $\delta 3.1-3.5$ was suggested to be attributed to the sugar groups present in martianine structure. Ten signals in the region of $\delta$ 6.7-7.6 indicated the presence of system aromatic. The NMR ${ }^{13} \mathrm{C}$ spectrum confirms the aromatic character of the

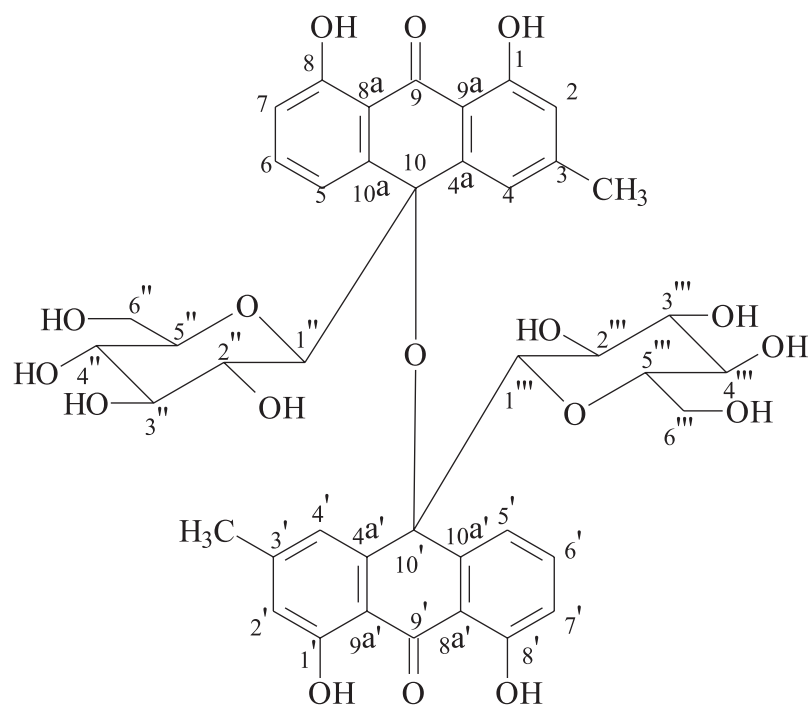

Martianine

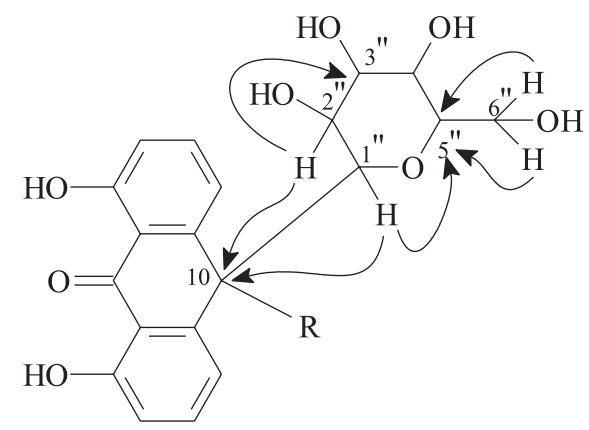

Figure 1. HMQC correlations observed in NMR spectrum. compound in question for the presence of the signals in the region of $\delta 115.1-162.5$, of these four they are of the oxygenated type, what is proven for your displacement, region of $\delta$ 162.2-162.9, due to your character dimeric, we have then one system aromatic type anthraquinonic

Table 1. ${ }^{1} \mathrm{H}$ and ${ }^{13} \mathrm{C}$ NMR data of the $2 \mathrm{D}$ NMR experiments $\left({ }^{1} \mathrm{H}-{ }^{1} \mathrm{H}\right.$ COSY, $\mathrm{HSQC}$, and $\mathrm{HMBC}$ ) of martianine

\begin{tabular}{|c|c|c|c|c|}
\hline \multirow[t]{2}{*}{ Position } & \multirow[t]{2}{*}{$\delta_{\mathrm{C}}$} & \multirow[t]{2}{*}{$\delta_{\mathrm{H}}$} & \multicolumn{2}{|l|}{ HMBC } \\
\hline & & & ${ }^{2} J_{\mathrm{CH}}$ & ${ }^{3} J_{\mathrm{CH}}$ \\
\hline & & (C) & & \\
\hline 1 & 162.5 & - & $\mathrm{H}-2$ & \\
\hline 1 ' & 162.9 & - & $\mathrm{H}-2^{\prime}$ & \\
\hline 3 & 148.9 & - & Me-3; H-4 & \\
\hline 3 & 148.1 & - & Me-3' & \\
\hline $4 a$ & 146.5 & - & $\mathrm{H}-4$ & $\mathrm{H}-1 "$ \\
\hline 4'a & 146.5 & - & & $\mathrm{H}-1$ "” \\
\hline 8 & 162.6 & - & & H-6 \\
\hline $8^{\prime}$ & 162.2 & - & & H-6 \\
\hline $8 a$ & 117.5 & - & & $\mathrm{H}-5 ; \mathrm{H}-7$ \\
\hline 8'a & 117.3 & - & & H-5'; H-7' \\
\hline 9/9' & 194.3 & - & & \\
\hline $9 \mathrm{a}$ & 115.1 & - & & H-2; H-4 \\
\hline 9'a & 115.3 & - & & H-2'; H-4' \\
\hline 10 & 76.8 & - & $\mathrm{H}-1 "$ & $\begin{array}{l}\text { H-4; H-5; } \\
\text { H-2" }\end{array}$ \\
\hline $10^{\prime}$ & 76.8 & - & $\mathrm{H}-1$ ", & $\begin{array}{l}\mathrm{H}-4^{\prime} ; \mathrm{H}^{\prime} 5^{\prime} \\
\mathrm{H}-2^{\prime}, "\end{array}$ \\
\hline $10 \mathrm{a}$ & 149.0 & - & & H-6; H-1" \\
\hline 10 'a & 149.1 & - & $\mathrm{H}-5$, & H-6"; H-1" \\
\hline 2 & 117.7 & $6.74(\mathrm{~s})$ & & Me-3; H-4 \\
\hline $2^{\prime}$ & 117.9 & $6.75(\mathrm{~s})$ & & Me-3'; H-4' \\
\hline 4 & 118.9 & $7.36(\mathrm{~s})$ & & $\mathrm{Me}-3 ; \mathrm{H}-2$ \\
\hline 4, & 120.1 & $7.27(\mathrm{~s})$ & & Me-3'; H-2' \\
\hline 5 & 118.8 & $7.4(\mathrm{dd}, J 7.6$ and $0.7 \mathrm{~Hz})$ & & $\mathrm{H}-7$ \\
\hline 5 , & 117.6 & $7.5(\mathrm{dd}, J 7.6$ and $0.7 \mathrm{~Hz})$ & & $\mathrm{H}-7$ \\
\hline 6 & 136.2 & $7.6(\mathrm{t}, J 7.6 \mathrm{~Hz})$ & H-5; H-7 & \\
\hline 6 & 136.9 & $7.6(\mathrm{t}, J 7.6 \mathrm{~Hz})$ & $\mathrm{H}-5$ & \\
\hline 7 & 118.0 & $6.9(\mathrm{~d}, J 7.6 \mathrm{~Hz})$ & & $\mathrm{H}-5$ \\
\hline 7 & 118.0 & $6.9(\mathrm{~d}, J 7.6 \mathrm{~Hz})$ & & $\mathrm{H}-5$ \\
\hline $\mathrm{Me}-3$ & 22.5 & $2.4(\mathrm{~s})$ & & $\mathrm{H}-2 ; \mathrm{H}-4$ \\
\hline Me-3' & 22.5 & $2.4(\mathrm{~s})$ & & H-2'; H-4' \\
\hline $1 "$ & 84.5 & $3.3(\mathrm{~d}, J 9.4 \mathrm{~Hz})$ & $\mathrm{H}-2 "$ & $\mathrm{H}-3 "$ \\
\hline 2" & 72.9 & $3.1(\mathrm{t}, J 9.4 \mathrm{~Hz})$ & $\mathrm{H}-1 " ; \mathrm{H}-3 "$ & $\mathrm{H}-4 "$ \\
\hline $3 "$ & 79.3 & $3.4-3.3(\mathrm{~m})$ & H-2"; H-4" & $\mathrm{H}-1 ”$ \\
\hline $4 "$ & 71.8 & $3.0-2.9(\mathrm{~m})$ & $\mathrm{H}-5 "$ & $2 \mathrm{H}-6 "$ \\
\hline $5 "$ & 81.1 & $3.0-2.9(\mathrm{~m})$ & $\mathrm{H}-4 " ; 2 \mathrm{H}-6 "$ & $\mathrm{H}-1 ”$ \\
\hline $6 "$ & 63.3 & $\begin{array}{l}3.6(\mathrm{dd}, J 11.3 \text { and } \\
2.6 \mathrm{~Hz}) ; 3.4(\mathrm{~m})\end{array}$ & $\mathrm{H}-5 "$ & $\mathrm{H}-4 "$ \\
\hline $1 "$, & 84.5 & $3.3(\mathrm{~d}, J 9.5 \mathrm{~Hz})$ & $\mathrm{H}-2 "$, & $\mathrm{H}-3 "$, \\
\hline $2 "$, & 72.9 & $3.1(\mathrm{t}, J 9.5 \mathrm{~Hz})$ & H-1"”, H-3"' & $\mathrm{H}-4, "$ \\
\hline $3 ”$, & 79.4 & $3.4-3.3(\mathrm{~m})$ & H-2"'; H-4"” & $\mathrm{H}-1, "$ \\
\hline $4 "$, & 71.8 & $3.0-2.9(\mathrm{~m})$ & $\mathrm{H}-5 "$ & $2 \mathrm{H}-6 "$ \\
\hline $5 "$, & 81.0 & $3.0-2.9(\mathrm{~m})$ & $\mathrm{H}-4 "$ "; $2 \mathrm{H}-6$ "' & $\mathrm{H}-1, "$ \\
\hline 6"” & 63.3 & $\begin{array}{l}3.5(\mathrm{dd}, J 11.3 \text { and } \\
2.6 \mathrm{~Hz}) ; 3.4(\mathrm{~m})\end{array}$ & $\mathrm{H}-5 "$ & $\mathrm{H}-4$ "', \\
\hline
\end{tabular}




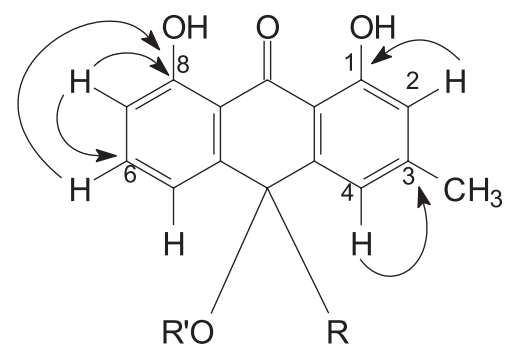

Figure 2. Long-range correlations in HMBC spectrum.

1.8-dihydroxyl. The other sign $\delta 22.5$ that shows the presence of a methyl probably linked to the aromatic ring. Summarizing, the ${ }^{13} \mathrm{C}$ NMR data indicated that the molecule presented two carbonyls $(\delta$ 194.3), twenty-four aromatic carbons $(\delta$ 115.1-162.9), twelve sugar carbons $(\delta$ 63.3-84.5), and two methyl groups ( $\delta 22.5)$. The absence of a signal near $\delta 180$, that it would be corresponding to another one carbonyl is in accordance with the anthron and affords the presence of a characteristic group as belonging to the scaffold of the compound in question.

This martianine structure is the product of the condensation of two molecules of 10-hydroxy-10glucosyl-chrysophanolanthron, its dimeric character was confirmed by the presence of the signals duplicates in the NMR ${ }^{1} \mathrm{H}$ and ${ }^{13} \mathrm{C}$ spectra and for its molecular mass of $\mathrm{m} / \mathrm{z} 802$, what it is in accordance with the total mass of two molecules of glucosyl-chrysophanolanthrons. The 2D NMR spectroscopic techniques had confirmed the assignments above cited and the presence of one unit of glucose to carbon 10, that it can be established by HMQC correlations of H-1" to C-10, H-2" to C-10, H-1" to C-5", H-2" to C-3", H1-6" to C-5", H2-6" to C-5" (Figure 1), which proves the connection of the chain of the sugar and C-10 anthron. The absence of the signal at about $\delta 101.00$ referring to anomeric carbon is not present, thus allowing concluding that the compound presents deoxy glucose in its structure. Long-range correlations in HMBC spectrum showed that at as correlations $\mathrm{H}-2$ to $\mathrm{C}-1, \mathrm{H}-4$ to $\mathrm{C}-3, \mathrm{H}-6$ to $\mathrm{C}-8, \mathrm{H}-7$ to $\mathrm{C}-6, \mathrm{H}-7$ to $\mathrm{C}-8$ confirming the skeleton anthron for this compound. The long-range correlations $\mathrm{H}-4 / \mathrm{H}-5 / \mathrm{H}-2$ " to C-10 (Figure 2) and $\mathrm{H}-4$ '/H- 5'/H-2"' to $\mathrm{C}-10$ ' confirm the position in $\mathrm{C}-10$ of side chain of sugar.

The conversion rates of glyceraldehyde-3-phosphate to 1-arseno-3-phosphoglycerate catalyzed by $T$. cruzi GAPDH in solutions of TEA buffer were monitored via ITC. The experiments were carried out in presence and absence of martianine and results can be found in Figure 3. The exothermic sharp peaks that can be seen in Figure 3A

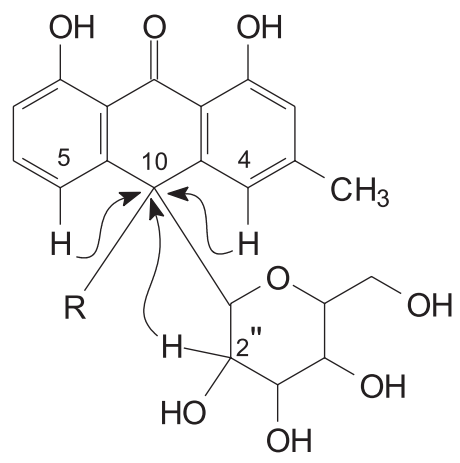

represent the heat of dilution for all injections. Among the peaks, the heat released from substrate depletion takes place at the steady state and the instrumental thermal power remains constant. There is a change in the steady state heatflow as the reaction rate increases after each injection. This keeps going until the baseline reaches the final steady state
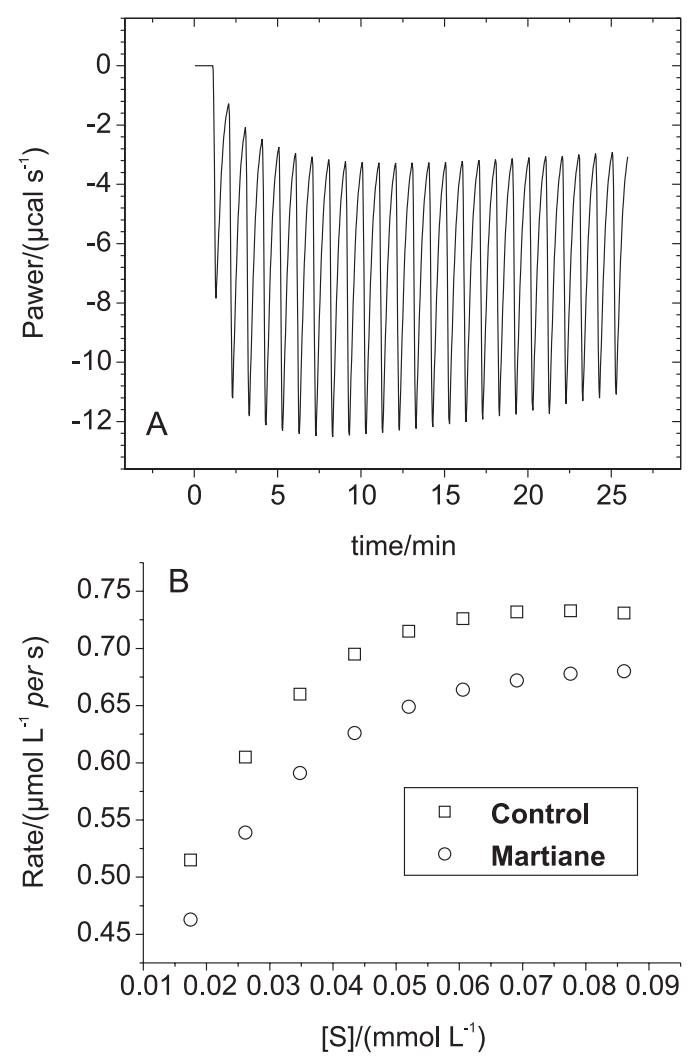

Figure 3. (A) Typical raw data for thermal power change as a function of time in the multiple injections assay and (B) Nonlinear least-squares fit of experimental data (dotted line) to Michaelis-Menten equation to determine kinetic parameters. Experiment control ( $\square$ ) and presence of $50 \mu \mathrm{mol}(\mathrm{O})$, 25 injections of G3P $5.0 \mathrm{mmol} \mathrm{L}^{-1}$ were titrated into the sample cell filled with the GAPDH buffered solution. Michaelis-Menten curve was plotted and data points were truncated when the reaction reached the maximum velocity. Under these conditions, product inhibition was thoroughly avoided. $\Delta \mathrm{H}_{\text {app }}=-5.76 \mathrm{Kmol}$ used for rate calculus was determined in a separate experiment. 
heat-flow level. The dependence of the reaction rate on glyceraldehyde-3-phosphate concentration follows typical Michaelis-Menten kinetics mechanism. The parameters $\mathrm{k}_{\text {cat }}$ and $\mathrm{K}_{\mathrm{M}}$ were obtained by fitting the raw data points to the Michaelis-Menten equation, using non-linear regression, and results can be seen in Table 2 .

Table 2. Kinetic parameters kcat, $\mathrm{K}_{\mathrm{M}}$ (observed values from curves in Figure 3 ) and $\mathrm{K}_{\mathrm{i}}$ of the martianine

\begin{tabular}{lccc}
\hline & $\mathrm{k}_{\text {cat }} /\left(\mathrm{s}^{-1}\right)$ & $\mathrm{K}_{\mathrm{M}} /\left(\mu \mathrm{mol} \mathrm{L}^{-1}\right)$ & $\mathrm{K}_{\mathrm{i}} /(\mu \mathrm{mol} \mathrm{L}-1)$ \\
\hline Control 1 & $177( \pm 2)$ & $11.8( \pm 0.7)$ & - \\
Martianine 1 & $156( \pm 3)$ & $10.6( \pm 1.0)$ & $28.4( \pm 0.5)$ \\
Control 2 & $117( \pm 1)$ & $12.5( \pm 1.1)$ & - \\
Martianine 2 & $105( \pm 1)$ & $14.6( \pm 0.4)$ & $26.2( \pm 0.9)$ \\
Average values & & $12.4( \pm 1.7)$ & $27.3( \pm 1.6)$ \\
\hline
\end{tabular}

The results depicted in Table 2 and Figure 3 suggest that the GAPDH enzyme is inhibited by martianine in a noncompetitive mechanism. The value of Michaelis-Menten constant $\left(\mathrm{K}_{\mathrm{M}}\right)$ does not change during the experiments and the catalytic constant $\left(\mathrm{k}_{\text {cat }}\right)$ diminishes at no $\mathrm{K}_{\mathrm{M}}$ expenses, as compared to control experiments. The stocked enzyme shows a loss of activity in function of the storage time. Nevertheless, when a control experiment is carried out previously to each inhibition assay the determined inhibition constant $\left(\mathrm{K}_{\mathrm{i}}\right)$ is reproducible. As can be seen in Table 1 even with the change in the $\mathrm{k}_{\text {cat }}$ (experiments realized in different days) the $\mathrm{K}_{\mathrm{i}}$ was still the same.

The enzyme glyceraldehyde-3-phosphate dehydrogenase (GAPDH) plays an important role in the life cycle of the Trypanosoma cruzi and it has become an important target in the drug discovery for Chagas disease. ${ }^{22}$ The high martianine affinity for the GAPDH it agrees to the some anthraquinones have shown activity against the parasite. ${ }^{5,23}$ The potential isothermal titration calorimetry has in the search for new inhibitors are thus put forward. It provides a direct measure of small molecule binding to enzymes as molecular targets in the drug discovery and development. The relationship of kinetic parameters to the drug-receptor interactions allows a fast description of substrate binding. The contribution to GAPDH catalysis is easily accounted for all processes taking place during the conversion to product. The catalytic efficiency of GAPDH enzyme entails the shape complementarities between enzyme and transition state. The catalytic efficiency $\left(\mathrm{k}_{\mathrm{cat}} / \mathrm{K}_{\mathrm{M}} 10^{7} \mathrm{~mol} \mathrm{~L}^{-1} \mathrm{~s}^{-1}\right)$ for the first control experiment is 1.4 whereas it comes to 0.9 when the second control experiment is carried out. In the presence of martianine the first measurement results in the catalytic efficiency to be 1.2 , and it comes down to 0.8 in the second one. Thus, the martianine small molecule does not enhance the catalytic efficiency of GAPDH. On the contrary, it reduces the overall catalytic efficiency so indicating the diminution of the $\mathrm{k}_{\mathrm{cat}}$ not at the expenses of $\mathrm{K}_{\mathrm{M}}$ that remains thoroughly constant. Overall, despite the change in the catalytic efficiency due to GAPDH loosing its activity this is not accounted for when the inhibitory constant is to be determined via isothermal titration calorimetry.

\section{Conclusions}

Martianine $\mathbf{1}$ is a of a new bianthrone glycoside isolated from Senna martiana Benth and the high martianine affinity for the $\mathrm{GAPDH}_{\mathrm{Tc}}$ enzyme suggests that this molecular class may be useful for the development of new drugs against Chagas disease.

\section{Supplementary Information}

Supplementary data of martianine structure as 1 and $2 \mathrm{D}{ }^{1} \mathrm{H}$ and ${ }^{13} \mathrm{C}$ NMR spectra are available free of charge at http://jbcs.sbq.org.br, as PDF file.

\section{Acknowledgments}

Authors acknowledge to Dr. N. P. Lopes (FCFRP, Universidade de São Paulo) for recording the mass spectra and also acknowledge to CNPq, FUNCAP and FAPESP for financial support.

\section{References}

1. Irwin, H. S.; Barneby, R. C.; Memoirs of the New York Botanical Garden; The American Cassiinae: A Synoptical Revision of Leguminosae Tribe Cassieae, subtribe Cassiinae in the New World, Vol. 35, Part 1, The New York Botanical Garden Press: New York, 1982, p. 465.

2. Barbosa, F. G.; Oliveira, M. C. F.; Braz-Filho, R.; Silveira, E. R.; Biochem. Syst. Ecol. 2004, 32, 363.

3. Alemayehu, G.; Abegaz, B.; Kraus, W. A.; Phytochemistry 1998, 48, 699.

4. Koyama, J.; Morita, I.; Tagahara, K.; Aqil, M.; Phytochemistry 2001, 56, 849 .

5. Mbwambo, Z. H.; Apers, S.; Moshi, M. J.; Kapingu, M. C.; Van Miert, S.; Claeys, M.; Brun, R.; Cos, P.; Pieters, L.; Vlietink, A.; Planta Med. 2004, 70, 706.

6. Vila, J. L.; Mollinedo, P.; Sterner, O.; Rev. Bol. Quim. 2003, $20,49$.

7. Pivatto, M.; Crotti, A. E. M.; Lopes, N. P.; Castro-Gamboa, I.; Rezende, A.; Viegas Jr., C.; Young, M. C. M.; Furlan, M.; Bolzani, V. S.; J. Braz. Chem. Soc. 2005, 16, 1431. 
8. Silva, G. H.; Teles, H. L.; Trevisan, H. C.; Bolzani, V. S.; Young, M. C. M.; Pfenning, L. H.; Eberlin, M. N.; Haddad, R.; Costa-Neto, C. M.; Araújo, A. R.; J. Braz. Chem. Soc. 2005, 16, 1463.

9. Sepúlveda-Boza, S.; Cassels, B. K.; Planta Med. 1996, 62, 98.

10. Coura, J. R.; Castro, S. L.; Mem. Inst. Oswaldo Cruz 2002, 97 , 3.

11. Campo, V. L.; Carvalho, I.; Allman, S.; Davis, B. J.; Field, R. A.; Org. Biomol. Chem. 2007, 5, 2645.

12. Aronov, A. M.; Suresh, S.; Buckner, F. S.; Van Voorhis, W. C.; Verlinde, C. L. M. J.; Opperdoes, F. R.; Hol, W. G. J.; Gelb, M. H.; Proc. Natl. Acad. Sci. U. S. A. 1999, 96, 4273.

13. Tomazela, D. M.; Pupo, M. T.; Passador, E. A. P.; Silva, M. F. G. F.; Vieira, P. C.; Fernandes, J. B.; Rodrigues, E. F.; Oliva, G.; Pirani, J. R.; Phytochemistry 2000, 55, 643.

14. De Marchi, A. A.; Castilho, M. S.; Nascimento, P. G. B.; Archanjo, F. C.; Del Ponte, G.; Oliva, G.; Pupo, M. T.; Bioorg. Med. Chem. 2004, 12, 4823.

15. Ladame, S.; Fauré, R.; Denier, C.; Lakhdar-Ghazal, F.; Willson, M.; Org. Biomol. Chem. 2005, 3, 2070.
16. Liñares, G. E. G.; Ravaschino, E. L.; Rodriguez, J. B.; Curr. Med. Chem. 2006, 13, 335.

17. Wiseman, T.; Williston, S.; Brandts, J. F.; Lin, L. N.; Anal. Biochem. 1989, 179, 131.

18. Hannaert, V.; Opperdoes, F. R.; Michels, P. A. M.; Protein Expression Purif. 1995, 6, 244.

19. Bradford, M. M.; Anal. Biochem. 1976, 72, 248.

20. Wiggers, H. J.; Cheleski, J.; Zottis, A.; Oliva, G.; Andricopulo, A. D.; Montanari, C. A.; Anal. Biochem. 2007, 370, 107.

21. ITC Data Analysis in Origin ${ }^{\circ}$, Tutorial Guide, Version 7.0, MicroCal, LLC: Northampton, MA, 2004.

22. Souza, D. H. F.; Garratt, R. C.; Araújo, A. P. U.; Guimarães, B. G.; Jesus, W. D. P.; Michels, P. A. M.; FEBS Lett. 1998, 424, 131.

23. Cuellar, M. A.; Salas, C.; Corte's, M. J.; Morello, A.; Maya, J. D.; Preite, M. D.; Bioorg. Med. Chem. 2003, 11, 2489.

Received: March 3, 2008 Web Release Date: April 24, 2009

FAPESP helped in meeting the publication costs of this article. 


\section{A New Bianthron Glycoside as Inhibitor of Trypanosoma cruzi Glyceraldehyde 3-Phosphate Dehydrogenase Activity}

Edângelo M. S. de Macedo, ${ }^{a}$ Helton J. Wiggers, ${ }^{b}$ Maria G. V. Silva, ${ }^{*, a, b}$ Raimundo Braz-Filho, ${ }^{c}$ Adriano D. Andricopulo ${ }^{d}$ and Carlos A. Montanari ${ }^{b}$

a Departamento de Química Analítica e Físico-Química, Departamento de Química Orgânica e Inorgânica, Universidade Federal do Ceará, 60455-970 Fortaleza-CE, Brazil

${ }^{b}$ Instituto de Química de São Carlos and IInstituto de Física de São Carlos, Universidade de São Paulo, 13560-970 São Carlos-SP, Brazil

'Setor de Química de Produtos Naturais, CCT, Universidade Estadual do Norte Fluminense, 28013-602 Campos dos Goytacazes-RJ, Brazil
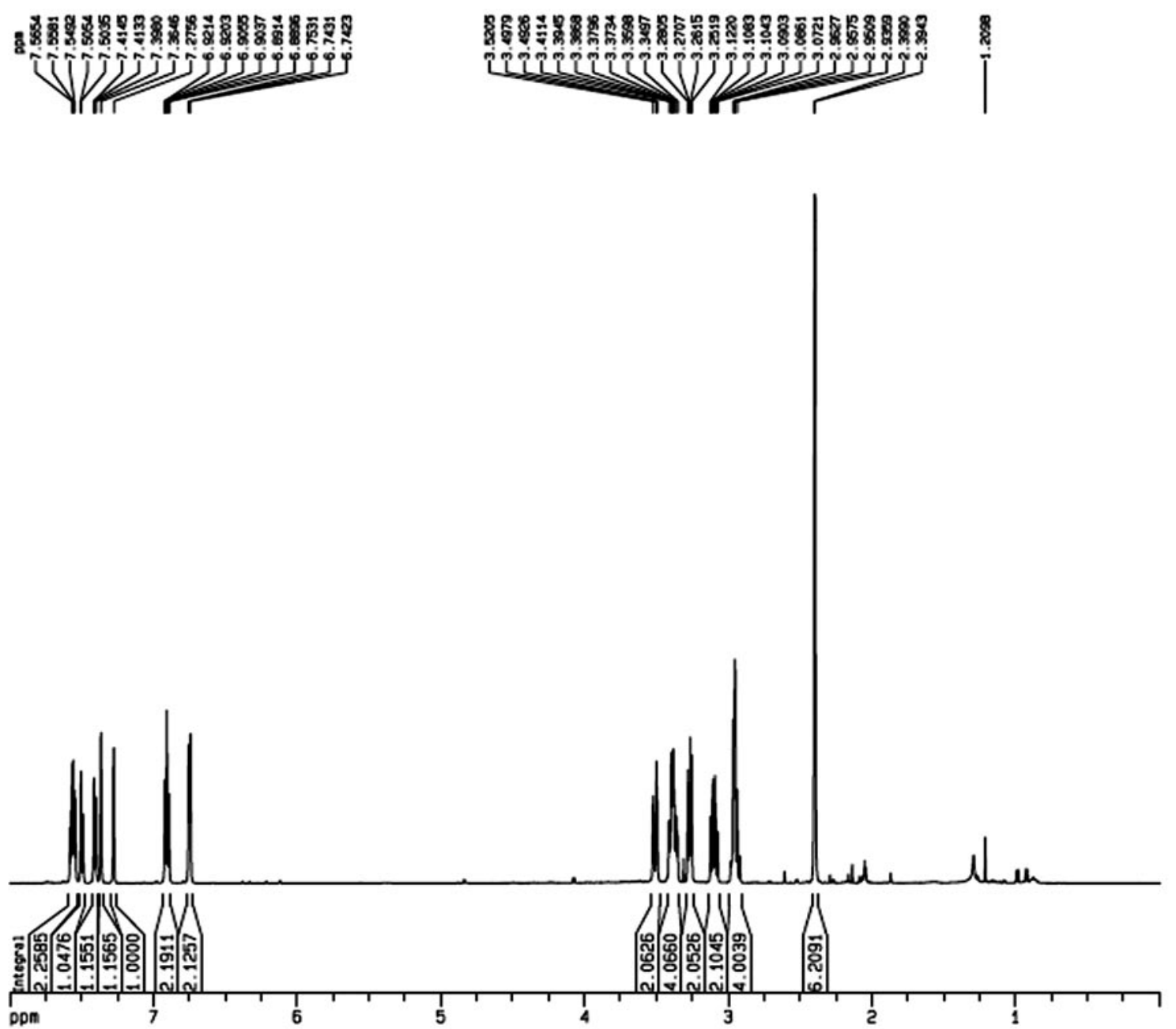

Figure S1. ${ }^{1} \mathrm{H}$ NMR spectrum of martianine. 


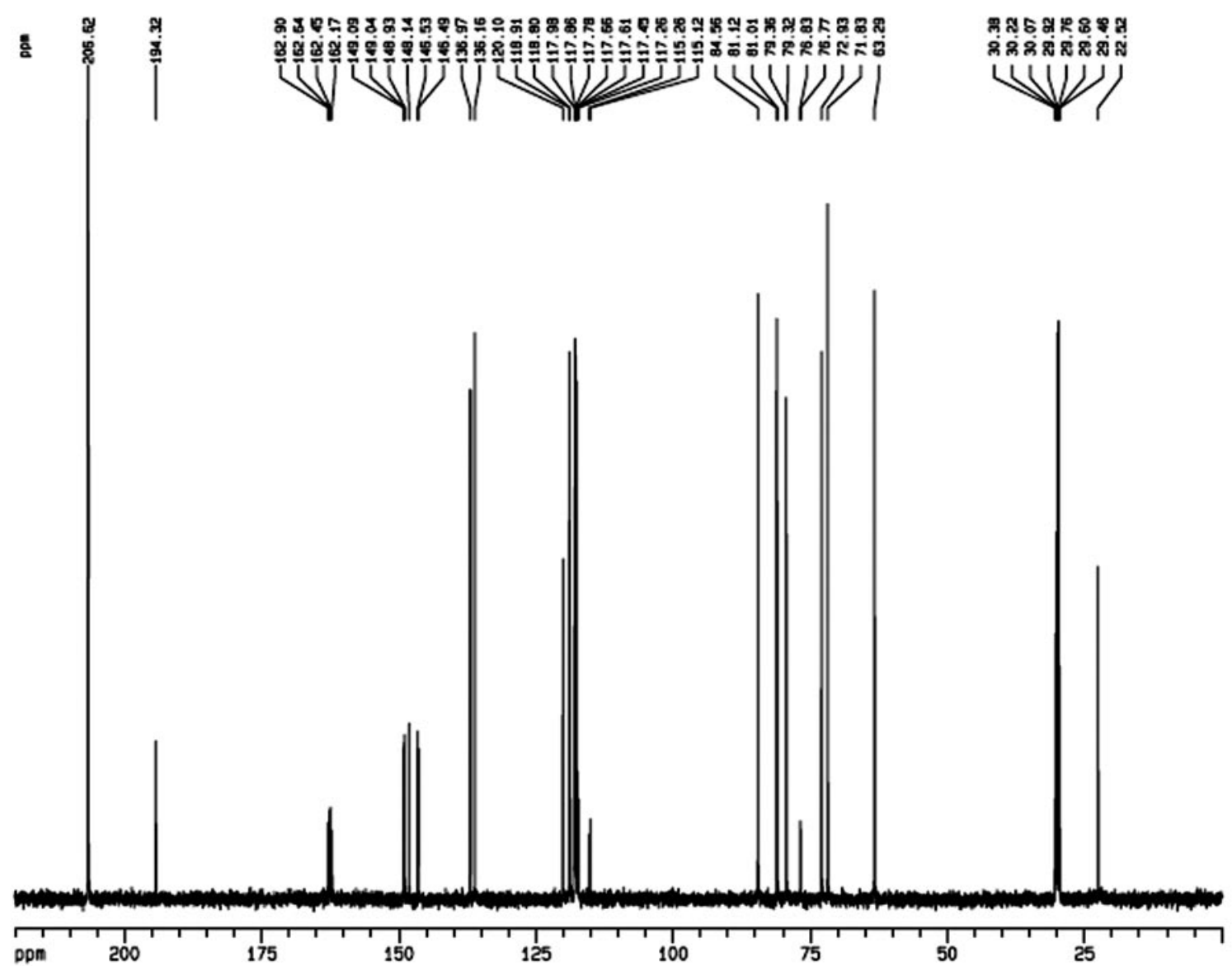

Figure S2. ${ }^{13} \mathrm{C}$ NMR spectrum of martianine. 